\title{
Constructing Peace in the Minds of People?: Roles of Japan in Psychosocial Reconstruction
}

\author{
Tadashi Iwami
}

This article seeks to add to the existing literature on Japan's peacebuilding by examining its involvement in the psychosocial reconstruction of children in conflictaffected regions. It demonstrates that to this end Japan has implemented creative, recreational activities, and, to a lesser extent, community-building strategies. This article argues that there are three important implications of Japan's involvement in psychosocial reconstruction for its own foreign policy: (1) psychological reconstruction can enhance its non-military approach to peacebuilding; (2) this field can potentially be another area of expertise in its own peacebuilding policy; and (3) in so doing, Japan may be able to carve out a niche in the field of international peacebuilding. This article concludes by identifying some limitations that can be developed into areas for future research.

Keywords Japan, Japan Foundation, peacebuilding, psychosocial reconstruction, art and sport, community-building

\section{Introduction}

On November 16, 1945, the United Nations Educational, Scientific and Cultural Organization (UNESCO) proclaimed in its constitution that "since wars begin in the minds of men, it is in the minds of men that defenses of peace must be constructed" (UNESCO 1945). The same constitution also added that ignorance, suspicion, and mistrust between individuals were common causes of wars and conflicts. The peace that the international community is trying to construct needs to be founded on "intellectual and moral solidarity of mankind" (ibid.). This proclamation has become a core philosophy of the organization. It suggests that the end of wars and conflicts by, for instance, signing peace accords, does not always equate to the realization of peace. Rather, it implies that it is the very beginning of a long journey of peacebuilding processes which eventually aims to build defenses of peace in people's minds. Peace will begin to emerge when we 
begin to acquire psychological well-being. That is not to say that healing minds is more important than political stability, economic recovery and growth, and social development. It is rather to stress that, alongside these vital components, helping those in conflict-affected regions regain their psychological well-being is an integral part of peacebuilding. In so doing, it can provide them with a sense of normalcy in their ordinary lives. How "a sense of normalcy" is defined is highly contingent as it can be dependent upon political, economic, social as well as moral, ethical and cultural grounds. Nevertheless, the proclamation of UNESCO points to the necessity of constructing a psychological sense of well-being.

The idea of peacebuilding in minds engrained in the core philosophy of UNESCO has recently been institutionalized within international frameworks and movements for peace. As early as 1992, "An Agenda for Peace" recognized this important point by asserting that "reducing hostile perceptions through educational exchanges and curriculum reform may be essential to forestall a re-emergence of cultural and national tensions which could spark renewed hostilities" (United Nations General Assembly 1992, emphasis added). Building on this, UNESCO took a leading role in promoting the so-called "culture of peace." The culture of peace was defined by the UN General Assembly in November 1997 as "values, attitudes and behaviours that reflect and inspire social interaction" and that created conditions for peace and its consolidation (United Nations General Assembly 1997, emphasis added). Since then, the culture of peace has become a popular global movement. Several global initiatives have taken place including the International Decade for a Culture of Peace and Nonviolent for the Children of the World (2001-2010), the International Decade for the Rapprochement of Cultures (2010), and the International Year for the Rapprochement for Culture (2013-2022). The key message of the development of these global initiatives is that peace cannot be cultivated without the fulfillment of psychological well-being among those in conflict-affected regions. This point was exactly what UNESCO Director Federico Mayor wrote in Peace and Conflict: Journal of Peace Psychology in 1995 during the early days of the development of the culture of peace concept. Mayor suggests, "psychological factors are especially important in bringing about this new departure [of the culture of peace]" (Mayor $1995,3)$.

The idea of constructing peace in the minds of people, which has been recognized in the constitution of UNESCO and in the subsequent concept of the culture of peace, is highly important to Japan's foreign policy. As I examine below, this idea is related to the discussion of one of Japan's foreign policy principles and pillars: human security and peacebuilding. As has been discussed elsewhere (Ishikawa 2014; Iwami 2016; Lam 2009), since the late 1990s Japan has stressed that human security is one of the core principles of its foreign policy. Since 2002, Japan has undertaken peacebuilding activities in the pursuit of human security for those people in conflict-affected regions such as Cambodia, Timor- 
Leste, Aceh in Indonesia, Mindanao in the Philippines, Sri Lanka, and, more recently, South Sudan. Building upon these developments, some Japanese leaders, intellectuals, and practitioners have incrementally recognized the relevance of the psychological element to the concept of human security and the praxis of peacebuilding.

The existing literature has provided us with a deeper understanding of domestic and international settings regarding the concept of human security and Japan's peacebuilding (Ashizawa 2014; Gilson 2007; Ishikawa 2014; Ishizuka 2005, 2006; Iwami 2016; Lam 2009, 2013, 2016; Osei-Hwedie 2011). Yet, Japan's peacebuilding in relation to the idea of peacebuilding in the minds of people has remained underexplored, and this article addresses this gap.

The focus of this article is predominantly on (but not exclusively limited to) children. There is no doubt that men and women are important because these adults are practical contributors to peacebuilding in many respects. Peacebuilding would be virtually impossible without their knowledge, skill, and effort to persevere. It is also true, and this article underlines this point, that in the long-run, peacebuilding would be unachievable without a fundamental focus on peace for the next generation. Children are the most vulnerable group in conflict situations, and yet absolutely vital to the success of long-term peacebuilding because, as U.S. President John F. Kennedy told us over a half century ago, "children are the world's most valuable resource and its best hope for the future" (Kennedy 1963).

Based on this conviction, this article fills the gap noted above by answering the following questions: does Japan promote the psychological well-being of those in conflict-affected regions as its part of peacebuilding? If so, what are the priorities? In order to answer these questions, this article first presents a theoretical framework that helps analyze Japan's peacebuilding from the perspective of peace psychology. Based primarily on the study of child psychology, it identifies three important sets of activities that help promote psychosocial reconstruction: (1) psychiatric treatment for the psychological wounds inflicted by conflict, namely Post-Traumatic Stress Disorder (PTSD); (2) community-building; and (3) creative and recreational activities. Second, in order for us to have a good understanding of Japan's peacebuilding efforts, this article turns its focus to examining its key tenets in relation to human security. In this examination, it takes into consideration the recent security policy change and continuity under the Prime Minister Shinzō Abe administration. It contends that Japan regards peacebuilding as an important means to ensure human security for those in conflict-affected regions. The third section of the article assesses the trilateral linkage between the psychological element, human security, and Japan's peacebuilding efforts. As touched upon above, there is a growing recognition among Japanese political leaders, intellectuals, and practitioners that a psychological element plays a role in adding value to the concept of human 
security. Since peacebuilding is a tool for Japan to promote human security, Japan's peacebuilding efforts should pay more attention to the fulfillment of psychological needs among those individuals in conflict-affected regions. Fourth, the central questions of this article is answered by investigating Japan's priorities. It shows that Japan focuses on implementing creative, recreational activities, and, to a lesser extent, community-building as forms of peacebuilding, and there is no evidence that any project includes psychiatric treatment of PTSD. The fifth section assesses Japan's peacebuilding policy and finds three broad implications: (1) Japan's involvement in psychosocial reconstruction enhances Japan's nonmilitary approach to peacebuilding; (2) this field can potentially be another area of expertise in its own peacebuilding policy; and (3) in so doing, Japan may be able to carve out a niche in the field of international peacebuilding. Lastly, the conclusion of the article identifies some limitations that can be explored in future research. They include the need for further analyses on the roles of NGOs and other national agencies, the strategic rationales behind Japan's involvement in psychosocial reconstruction as a part of peacebuilding, and the psychological impact on adults.

\section{Psychosocial Reconstruction as an Integral Part of Peacebuilding}

The study of psychology in relation to war and peace is not new. It dates back to before World War I when, for instance, psychologists examined changes in the degree of nationalism between peace time and war time. However, the discipline of peace psychology began to flourish in the 1980s. As the bipolar structure of the international system dissipated and the Cold War ended, intra-national and ethnic conflicts, some of which had been obscured by the bipolar structure of the time, began to erupt more frequently than during the Cold War. This new challenge led many scholars from other academic disciplines to take the essence of psychology into account when analyzing the causes and effects of peace and conflict. The rise of new challenges and increasing interest from those in other disciplines in the field of psychology has, in part, contributed to producing the discipline of peace psychology (Christie, Wagner, and Winter 2001).

The development of the peace psychology discipline is critical to our understanding of peacebuilding processes. Experts on this discipline such as Michael Wessells and Carlinda Monteiro (2001) argue that peacebuilding processes encompass interlinked tasks of political, economic, and social recovery and reconstruction. Along with reconstructing resilient political and economic infrastructures and systems, social reconstruction needs to include a wide range of tasks for achieving tangible and intangible goals. For them, these goals include rebuilding civil society, reintegrating displaced people and former combatants into their original communities, creating trust and confidence in the community 
to which they belong, and ultimately generating a sense of community. Psychosocial reconstruction, which can be defined as a set of activities that enhance individuals' inherent psychological well-being, together with a sense of community is considered an important integral part of peacebuilding (ibid.). In short, as the constitution of UNESCO in 1945 also states, constructing peace in the minds of people also matters in these processes.

The physical wounds of conflict such as injuries and other diseases among those in conflict-affected regions need to be treated promptly and this treatment is absolutely vital to the survival of those in conflict-affected regions. However, this article focuses exclusively on the healing of psychological impacts from conflict. Based on this definition of psychosocial reconstruction in peacebuilding, three types of activities can be identified.

First, the psychological wounds of conflict need to be healed through psychiatric treatment. Conflict causes psychological distress among many individuals in conflict-affected regions. This is triggered by their own experiences of physical harm, the loss of and/or separation from their relatives and belongings, and other traumatic conditions which result in poverty and starvation (ibid.). To help overcome such traumatic experiences, clinical diagnosis of PTSD and the subsequent psychiatric treatment are important steps in recovering from the traumatic experiences of conflict. Brechtje Kalksma-Van Lith (2007) contends that this psychiatric treatment should involve psychotherapy and counselling by mental health experts for a long period of time.

The second type of psychological reconstruction is closely related to the social dimension. It is essential that community-building be undertaken to regain a sense of healthy and positive psychosocial well-being. According to Wessells and Monteiro (2001), psychological distress of those in conflict-affected areas stems in part from "the disruption of traditions and patterns of daily living." In order to help return these people to the normal routines of their daily lives it is imperative that psychosocial reconstruction "puts culture at the center" and emphasizes their traditions that "provide a sense of community and support and to build processes of dialogues and participation that strengthen civil society." In contrast, "failure to include psychosocial assistance in programs of post-war reconstruction is likely to leave wounds and social cleavages that invite additional conflict."

Kalksma-Van Lith $(2007,9)$ also points out the relevance of communitybuilding as a form of psychosocial reconstruction in peacebuilding. Focusing on the psychological impact on children, she suggests that community-building is an effective task because it provides them with "ways of coping with stress situations and the after-affects of trauma." Community-building activities include the restoration of social environments that resemble normal life patterns. For instance, restoring learning environments for children at school is effective not only because it provides them with an opportunity to learn, but also because 
it "offers them a sense of predictability and security" in their lives. Other activities include the promotion of cultural rites and traditional events and the development of tight social networks in a local community through which individuals can regain a sense of belonging and personal dignity (ibid., 8).

The third type of psychosocial reconstruction is the implementation of creative and recreational activities. Arts and sports are known to be powerful means to increase psychosocial well-being in individuals in conflict-affected regions because they can enhance their daily lives which in turn helps heal their psychological trauma. From the child psychosocial perspective, Kalksma-Van Lith suggests that these creative and recreational activities encompass performing drama and story-telling, playing music, dancing as well as playing sports and games. They can "offer the opportunity to play and have fun as a counterbalance to stressful experiences and the impoverished world surrounding children in the aftermath of war" (ibid.). Other scholars such as Craig Zelizer (2003) and Michael Shank and Lisa Schirch (2008) also second the proposition that the encouragement of creative arts is an essential means of peacebuilding. Others like Roger Levermore and Aaron Beacom (2009, 9-10) also support the key role of recreational activities like sports in the alleviation of tension caused by conflict fought along ethnic lines and community-building.

Furthermore, a recent social psychological study conducted by Jon Welty Peachey and others (2013) finds that sports can be a vital tool for peacebuilding and it will be particularly effective when it is accompanied with broader cultural, social, artistic and educational activities including choirs, creative writing, dance, digital photography, symphonies, theater and visual arts. This study concludes that intercultural communication through creative and recreational activities helps reduce inter-group prejudice and promote self-efficacy so that some participants may become community leaders. Others conclude that sports can contribute to peacebuilding efforts although the linkage remains relatively unexplored. (Schnitzer et al. 2013).

It is important to note that psychosocial reconstruction, which can be approached broadly through the three types of activities identified above, does not supplant other forms of peacebuilding activities. Neither is it the only means to building peace in conflict-affected regions. It is not a panacea for all difficulties in peacebuilding. As Akiko Fukushima $(2008,99)$ implies, it could merely be "a drop in the ocean" where those children and adults in conflict-affected regions need tangible support such as safe water, food, shelter, and the provision of more stable state infrastructure. Ogura $(2010,19)$ also notes that the continued assurance of physical security is a baseline for projects that focus on meeting psychological needs. Nevertheless, this article emphasizes that psychosocial reconstruction is an essential part of peacebuilding. It provides us with powerful insight into the practice of peacebuilding, and it gives us an additional perspective on peacebuilding from an intangible dimension. 
Table 1. Psychosocial Reconstruction in Peacebuilding

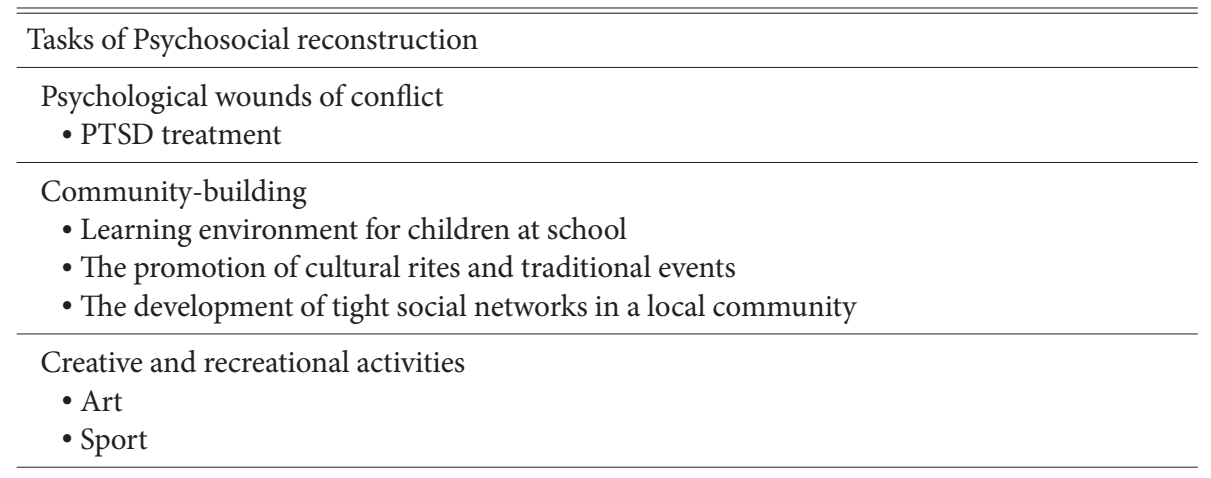

Taken together, the findings of these peace psychologists discussed above serve as a theoretical framework for this article: the healing of psychological wounds from conflict among individuals, community-building through cross-conflict dialogue and intercultural communication between them, and the restoration of their normal patterns and routines through creative and recreational activities such as arts and sports do matter in peacebuilding. The theoretical framework employed here is summarized in Table 1.

\section{Japan's Peacebuilding: Promoting Human Security by Non-military Means}

In order to examine whether, and, if so, how Japan engages in psychosocial reconstruction as part of its peacebuilding, it is important for us to have a good understanding of the key tenets of Japan's peacebuilding. By taking into account some implications of Japan's recent security legislation reforms for peacebuilding, this section highlights an important linkage between peacebuilding and the concept of human security. Japan's peacebuilding is underpinned by a nonmilitary approach which is considered a crucial tool for the country to promote individual human security in conflict-affected regions. It needs to be noted at the outset that although the Abe administration's security legislation in 2016 has generated heated debates and concerns over Japan's assertive role in regional security, "Japan's security policy remains far more self-restrained than any other major economic power" (Liff 2015, 89). This security posture, more specifically a non-military approach, largely applies to its own peacebuilding policy for two major reasons.

First, the concept of human security continues to be one of the cornerstones of Japan's peacebuilding policy since the development of the concept under the Keizō Obuchi administration in the late 1990s. Human security was regarded as 
a condition under which both an individual's "freedom from want" and "freedom from fear" were assured. Since the conceptual development of human security, Japan has continued to focus on freedom from want which emphasizes the importance of long-term political, economic, and social development. However, according to Honna (2012), there has been increasing amount of evidence that Japan is also becoming more interested in issues surrounding "freedom from fear" that stress the adequate protection of individuals against physical threats. Freedom from fear is often considered the conceptual basis of the Canadian government's idea of Responsibility to Protect (R2P), which was later endorsed by the United Nations (UN). The idea of R2P states that in a condition under which individuals in conflict-affected regions are being faced with physical threats to their survival, it is a national government's responsibility to protect them. If the national government does not take the necessary action, then it is ultimately the international community's responsibility to act on behalf of the threatened individuals, even if this requires military intervention. Most recent analyses on the perception of human security among Japanese leaders and intellectuals conducted by Honna and Kurusu show that there is increasing recognition among them that these two freedoms are interlinked with one another (Kurusu $2016,19)$, and that Japan is becoming more comfortable with some elements of R2P (Honna 2012, 109).

Critics may argue that this interlink in the concept of human security is an example of the recent change in Japan's security policy to be more assertive and militaristic. Nevertheless, Japan has continuously made a clear distinction between what it can do and what it cannot do to assure freedom from want and fear despite the emerging positive view towards R2P. Even though conducted on humanitarian grounds, military intervention continues to be excluded from Japan's foreign policy choices. This attitude is widely shared by Japanese leaders and intellectuals (Kurusu 2016, 30). Honna also points out that it will be through "engineers, doctors, agronomists, teachers, and other experts in capacity building," not combat forces, that Japan can fulfil the principle of human security (Honna 2012, 109).

Second, Japan has employed a non-military approach to its own peacebuilding practices since the development of the concept of peacebuilding in 2002. For instance, Japan regards diplomatic dialogue and the holding of international conferences as an important component of its peacebuilding practices. This approach is institutionalized through the regular organization of international forums such as the Tokyo International Conference for African Development (TICAD), and by the continued commitment to the UN Peacebuilding Fund as a funding member. Japan's leadership has organized peace talks in, for example, Cambodia, Aceh in Indonesia, and Mindanao in the Philippines. Other peacebuilding activities include Japan's intellectual leadership role in the Commission of Human Security convened in 2001, and an effort to 
financially support the Trust Fund for Human Security which was created by the UN (Edström 2011, 27-38; Kurusu 2011).

On the ground level, Japan's peacebuilding has also consisted of hybrid efforts including the provision of official development assistance (ODA), and participation in UN-authorized peacekeeping operations. The recent revision of Japan's ODA charter and the enactment of security legislation have some implications for these two efforts. First, Japanese ODA can now be used by the military forces of recipient countries. Second, the rules of engagement for the use of weapons within the Japanese Self-Defense Forces (SDF) have widened. Weapons can be used to protect not only themselves, but also other foreign military personnel, other civilian officials, and non-governmental workers cooperating with them.

Nevertheless, Japan's on-the-ground peacebuilding is guided by the nonmilitary approach (Lam 2009, 13). The provision of ODA is limited to only two non-military activities, namely humanitarian assistance (not R2P-style humanitarian military intervention), and disaster relief. In fact, human security has continued to be one of the core targets of Japan's ODA (Carvalho and Potter 2016). With regard to the use of weapons, it is still unconstitutional and highly improbable that SDF personnel will conduct lethal combat activities (Liff 2015, 90). Despite its moral purpose, the laws do not allow them to join humanitarian military intervention, let alone military operations such as those undertaken by German military personnel as part of the North Atlantic Treaty Organization (NATO) during the bombing in Kosovo and military operations in Afghanistan.

If Prime Minister Abe believes in ensuring human security for those in conflict-affected regions through military means, then he would utilize humanitarian military intervention and stand on principle that it is the most promising option based on the concept of human security. Following the security legislation reforms and the degradation of the post-conflict situation in South Sudan in July and August 2016, he could have sent SDF's highlytrained Special Forces there for the purpose of reinforcing the already deployed logistical personnel. Abe could have strategically utilized this situation as an opportunity to set the precedence for humanitarian military action. Despite many people's assumptions to the contrary, Abe has still decided against such military intervention as an appropriate security policy tool to assure human security and build peace, although there is the possibility that SDF personnel may be allowed to help protect other UN peacekeepers in November 2016 (Japan Times 2016).

Furthermore, Japan has continued to commit itself to human resource development for fostering civilian peacebuilders at home. Beginning in 2007, the Hiroshima Peacebuilder Center (HPC), in collaboration with the Ministry of Foreign Affairs (MOFA) and UN Volunteer (UNV), has been the core implementer of a program that puts a strong emphasis on the promotion of human security. In a sense, it is an educational initiative that fosters future 
human security promoters. Importantly, Japan regards this "at-home" human resource development program organized by the HPC as another key task in its peacebuilding despite its alternative way of performing this task (Iwami 2016; Uesugi 2012a).

These key tenets support Japan's non-military approach to peacebuilding. Also, the discussion above directs us to propose that one of the critical means to promote human security for Japan is non-military peacebuilding in conflictaffected regions. In the context of R2P, Honna $(2012,103)$ writes, "Japan successfully incorporated the peace-building agenda into the scope of human security." Kurusu $(2011,116)$ notes that "a tendency to link these activities [development assistance that promotes freedom from want] with post conflict peace-building can be discerned." In her most recent article, Kurusu $(2016,8)$ reiterates that human security is often incorporated into peacebuilding activities. Based on the various case studies in Southeast Asia, Peng Er Lam also supports this proposition by explicitly writing, unlike the more forceful approach often adopted by NATO in addressing internal conflicts, "Tokyo's consolidation of peace is guided by the concept of 'human security"' (Lam 2009, 13). Japan's peacebuilding in these three areas of focus (in international forums, on the ground, and at home) is based on the concept of human security.

\section{Psychosocial Element in Human Security and Peacebuilding}

More recently, there is a growing recognition among Japanese leaders and intellectuals that human security is highly related to the idea of "freedom to live in dignity," or what I broadly define as an inherent sense of psychosocial wellbeing as a human. Kurusu's 2016 report suggests this point. For instance, one Japanese politician mentioned during an interview the importance of a sense of community. Kurusu paraphrases his words as "even if our needs such as goods and education are met, if a person feels he/she is needed by none and left out, we do not think his/her human security has been achieved" (Kurusu 2016, 36 emphasis added). One scholar also told Kurusu that a psychosocial aspect was as important as other tangible elements of human security (ibid.). A staff member at the Japan International Cooperation Agency (JICA) also reiterated the same point stating during an interview "[the] freedom to live in dignity, or the psychological aspect" is a critical but overlooked component of human security (ibid., 40). This series of the interviews led Kurusu to conclude that the psychosocial aspect implied in the idea of the freedom to live in dignity can generate added value to the concept and praxis of human security that Japan promotes to the world. It appears that some Japanese leaders, intellectuals, and JICA staff members have begun incrementally recognizing that an inherent sense of psychological well-being as a human being can also be the hallmark of the concept of human 
security. In this light, it is conceivable that Japan's peacebuilding requires activities that enhance an inherent sense of psychological well-being among individuals in conflict-affected regions.

Has Japan considered this point in the context of peacebuilding? The answer to this question is yes, but Japan has focused on peacebuilding through cultural initiatives. Peacebuilding through cultural initiatives became an increasingly popular idea during the Junichiro Koizumi administration (2001-2006). One of the signs of this was the establishment of the Council on the Promotion of Cultural Diplomacy (CPCD) in December 2004. The main purposes of the CPCD were to examine the effectiveness of Japan's cultural and public diplomacy and to provide Koizumi with practical foreign policy tools within this frame. What is relevant to the discussion of peacebuilding was that, among other objectives, the CPCD stressed Japan's role in conflict prevention and promotion of mutual understanding through cultural exchanges in conflict-affected regions. In particular, the council emphasized that Japan was a country that could "understand the difficulties facing contemporary non-Western societies that are struggling to achieve modernization," given its own modernization processes that derived from the intertwining of traditional and Western cultures (CPCD 2005). The report stated:

By taking advantage of its position, Japan can promote mutual understanding between the East and the West, the North and the South, nations, regions, civilizations, or cultures without becoming entangled in clashes between civilizations, ideologies or religions. By so doing, Japan can play an active role in building peaceful and stable international and regional relations as a 'peaceful nation of cultural exchange'. Furthermore, this is what is expected by the international community (ibid.).

The CPCD's report also recommended that Japan would need to incorporate the cultural element into its own way of building peace in conflict regions because it would help "cultivate mutual understanding and trust between different cultures and civilizations for conflict avoidance" in those regions (ibid.). Although the term "psychosocial" or "psychological" did not appear in this advisory report, Japan began recognizing the link between peacebuilding through cultural initiatives and an element of psychosocial reconstruction that helps promote the "freedom to live in dignity" for the first time.

Recognizing this, the Japan Foundation, a semi-governmental agency of Japan that promotes cultural and public diplomacy, raised a more explicit voice in favor of the incorporation of the psychosocial element into Japan's peacebuilding through cultural initiatives. Kazuo Ogura, the president of the Japan Foundation at that time, made the claim by noting that peace would not be built solely by providing physical elements such as basic human needs and infrastructure. He argued that: 
Rehabilitating physical infrastructure such as bridges, roads, schools, housing, hospitals and water and sewage systems in an area afflicted by a dispute or conflict is not enough. Clearing up misperceptions and misunderstanding, and dispelling distrust between disputing parties is essential for peacebuilding (Japan Foundation 2008b, 2).

Ogura also suggested that root causes of conflict would remain in place unless mutual understanding and trust between those individuals in the area afflicted by conflict were promoted. Therefore, he concluded that "to build peace in the true sense of the term, it is essential to make reconstruction efforts with physical and economic assistance but also efforts with regard to the cultural aspects including those that meet the psychological needs of people in the conflict area" (ibid., emphasis added). Additionally, in an interview with the author conducted in July 2012, Ogura reiterated that rebuilding "human heart and spirit" through cultural exchange was a key part of Japanese peacebuilding (Ogura 2012).

This suggests that there is growing recognition in Japan that a psychological element plays a partial role in promoting human security. Also, since peacebuilding is a means for Japan to promote human security, one of the peacebuilding objectives is expected to be the fulfillment of psychosocial needs among those individuals in conflict-affected regions.

\section{Japan's Priorities in Psychosocial Reconstruction in Peacebuilding}

Does Japan undertake psychosocial reconstruction in conflict-affected regions as part of its peacebuilding? If so, what tasks does it prioritize? It has to be noted at the outset that the scope of this article is limited to the work of the Japan Foundation due to the constraints of time and space. While it acknowledges the need for further examinations of other government agencies such as MOFA and JICA, it highlights that the Japan Foundation supports various non-governmental organizations (NGOs) and collaboratively they undertake various forms of psychosocial reconstruction projects.

Based on the theoretical framework taken from the study of peace psychology, this section examines twenty-two projects which were either "organized or funded by the Japan Foundation" (Japan Foundation 2008b, 7). Nineteen of these projects have been identified as key projects in the Japan Foundation's "The Roles of Cultural Initiatives in Peacebuilding" report produced in 2008 (ibid.), and the other three projects have appeared on the website of the Japan Foundation after the publication of the 2008 report (Japan Foundation 2008a, 2010, 2013). Table 2 shows the name of the project, the date of commencement, and the country in which a project took place in chronological order based on the date of the 
Table 2. List of Projects Undertaken by the Japan Foundation

\begin{tabular}{|c|c|c|c|}
\hline $\begin{array}{l}\text { Project } \\
\text { Number }\end{array}$ & Date & Name of project & Country \\
\hline 1 & $1980 \mathrm{~s}$ & $\begin{array}{l}\text { Production and Performance by the Philippines } \\
\text { Educational Theater Association (PETA) }\end{array}$ & $\begin{array}{l}\text { Philippines } \\
\text { Japan }\end{array}$ \\
\hline 2 & $1994 \mathrm{Nov}$ & Preservation and Restoration Project for Angkor Ruins & Cambodia \\
\hline 3 & $2003 \mathrm{Nov}$ & An Exhibition of Pictures Drawn by Afghan Children & Japan \\
\hline 4 & $2004 \mathrm{Feb}$ & Joint Publication of "Kashmir Peace Picture Books" & Nepal \\
\hline 5 & $\begin{array}{l}2004 \mathrm{Feb} / \\
2005 \mathrm{Mar}\end{array}$ & $\begin{array}{l}\text { Invitation Performance of Al-Kasaba Theater from } \\
\text { Palestine }\end{array}$ & Japan \\
\hline 6 & 2004 Oct & $\begin{array}{l}\text { Invitation Performance of "Message Carried by Ship" } \\
\text { by Al-Murwass, a contemporary theatrical troupe } \\
\text { from Iraq }\end{array}$ & Japan \\
\hline 7 & 2004 Nov-Dec & $\begin{array}{l}\text { Joint Production and Performance of "Memories of } \\
\text { Legend" by producers from five South Asian countries }\end{array}$ & Japan \\
\hline 8 & $2004-6$ & Israel-Palestine "Peace Kids Soccer" & Japan \\
\hline 9 & 2005 Mar & $\begin{array}{l}\text { Theater Workshop by a Children's Theater Troup } \\
\text { "Kazenoko" }\end{array}$ & $\begin{array}{l}\text { Timor-Leste } \\
\text { Indonesia }\end{array}$ \\
\hline 10 & $\begin{array}{l}2005 \mathrm{Mar} / \\
2005 \mathrm{Oct}\end{array}$ & Dialogue for Peace and Stability in the Balkans & $\begin{array}{l}\text { Serbia } \\
\text { Bulgaria }\end{array}$ \\
\hline 11 & 2005 Apr & $\begin{array}{l}\text { Showing of the Iraq Film "Underexposure" at the } \\
\text { Arab Film Festival } 2005\end{array}$ & Japan \\
\hline 12 & $2005 \mathrm{Jul}$ & $\begin{array}{l}\text { Palestine-Israel-Japan "Youth Exchange Project for } \\
\text { Peace" }\end{array}$ & Japan \\
\hline 13 & 2005 & Resuscitation of Afghan Ceramic Art: Istalif Ware & $\begin{array}{l}\text { Afghanistan } \\
\text { Japan }\end{array}$ \\
\hline 14 & $\begin{array}{l}2006 \text { Jan-2007 } \\
\text { Aug }\end{array}$ & $\begin{array}{l}\text { Sponsoring of a TV program: Soccer Anime "Captain } \\
\text { Tsubasa" }\end{array}$ & Iraq \\
\hline 15 & 2006 May & $\begin{array}{l}\text { Donation of Children's Books to the Muthanma } \\
\text { Governorate, Smmawah }\end{array}$ & Iraq \\
\hline 16 & 2007 Apr/Aug & First Theater Workshop for Children in Aceh & Indonesia \\
\hline 17 & $2007 \mathrm{Jul}$ & Palestine Youth Theater "Longing to the Sea" & Japan \\
\hline 18 & $2007 \mathrm{Jul}$ & Children’s Play "Parachute" from Croatia & Japan \\
\hline 19 & $2007 \mathrm{Jul}$ & Lecture by Mr. Gado, a Kenyan Political Cartoonist & Japan \\
\hline 20 & 2008 Aug & Children's Conference in Aceh & Indonesia \\
\hline 21 & $2010 \mathrm{Dec}$ & Second Theater Workshop for Children in Aceh & Indonesia \\
\hline 22 & 2013 Aug & $\begin{array}{l}\text { Randooga Music Workshops and Concert in } \\
\text { Batticaloa and Galle }\end{array}$ & Sri Lanka \\
\hline
\end{tabular}




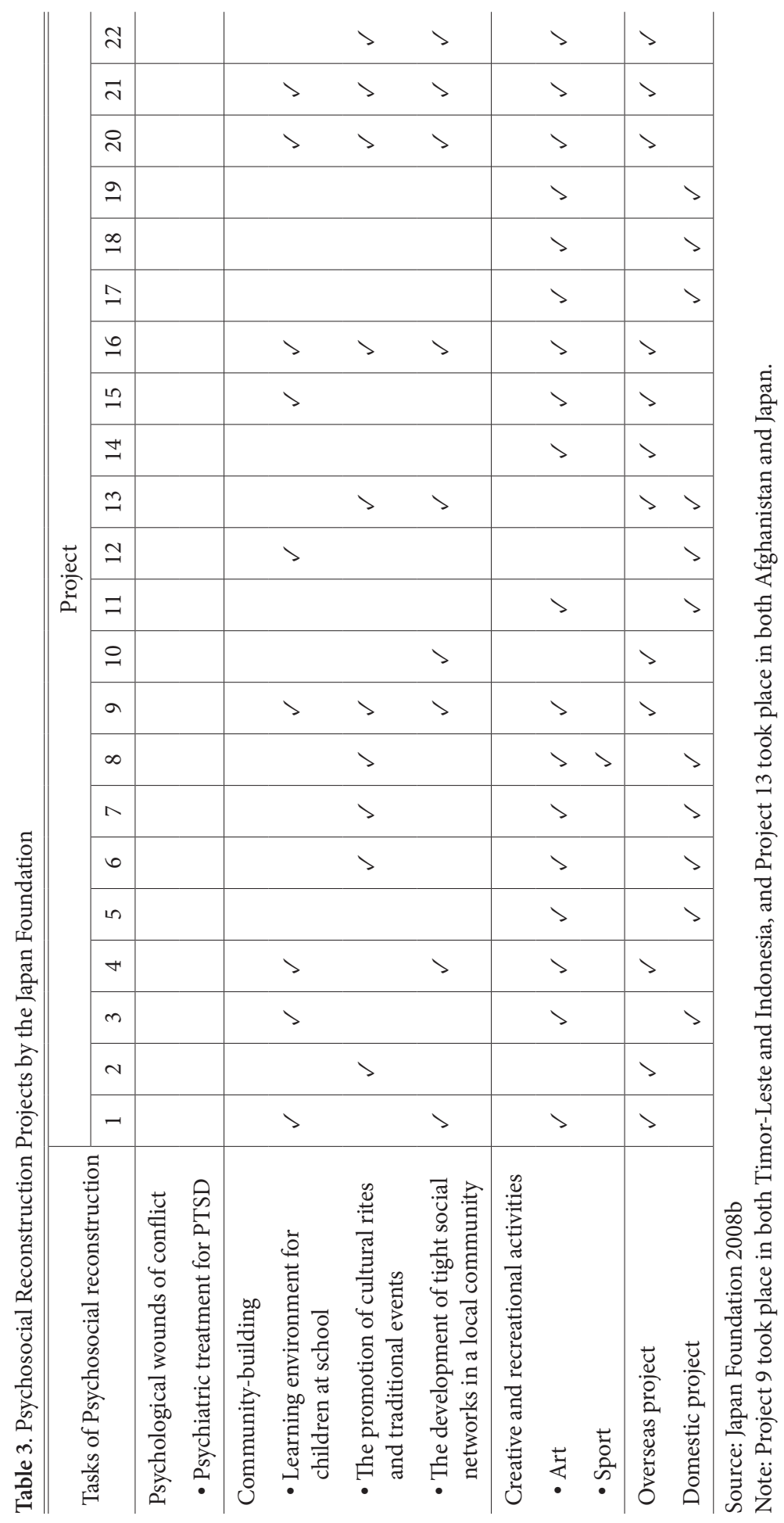


commencement. Table 3 indicates prioritized tasks in each project based on the theoretical framework designed above.

This research is by no means exhaustive; however it underlines several important characteristics and priorities of Japan's psychosocial reconstruction in the field of peacebuilding. First, almost all projects focused on creative activities and encompass various forms of arts. For instance, Project 4 aimed at both creating a venue to meet writers, painters, editors, and child education experts from India and Pakistan in a third-party country, Nepal, and jointly publishing seven children's books. The ultimate goals of this project were to promote mutual understanding and confidence-building among the artists from these two countries, and pass along these emotions to the children at home through children's book. The Japan Foundation's report wrote that "the stories contained in the co-produced picture books depict the processes of realizing humanity by stopping fighting and working on a common goal. They thus unravel the psychology behind the roots of conflict" (Japan Foundation 2008b, 13). Other projects such as Project 9 in Timor-Leste, Project 16 and 21 in Aceh, Indonesia, and Project 22 in Sri Lanka, focused on helping children to express themselves freely by organizing workshops and giving musical and theatrical performances. These activities provided them with opportunities to regain self-confidence, nurture high hopes, and eventually help them heal their own psychological wounds by themselves.

Second, some overseas projects encompassed activities that aimed at promoting community-building. One example was Project 13 through which some Afghanistan ceramists in the region of Istalif (approximately $50 \mathrm{~km}$ north of Kabul) attempted to revive their traditional ceramic industries. The Japan Foundation supported a project for cultural and human exchanges between Afghan and Japanese ceramists in order to help the Afghan practitioners acquire and strengthen knowledge and skills.

The reinvigoration of a local industry that was heavily reliant on local and cultural traditions was an important step for building peace not merely because it could potentially be the main source of income for that local community, but also because it could provide a sense of community and belonging to the locals. It would be nearly impossible for them to build their community without a sense of community in the first place. This means that despite the small scale of the project when compared to Japan's large financial and technical foreign aid to Afghanistan, it became a crucial means for Japan to help the Afghan locals regain their self-esteem and courage for post-war reconstruction (Fukushima 2008, 98). In this light, this project was an exemplar of psychosocial reconstruction. For the same reason, it is not difficult to imagine that those projects including theatrical activities, such as Projects 9, 16, 21 and 22 in Table 3, also had a positive impact on tightening social networks in these local communities given the community involvement in these projects. 
Third, almost half of the projects identified above took place in Japan. One commonality among them was that creative artists, performers, directors, and producers were invited to Japan for exhibitions and performances. Through these projects, they had a number of opportunities to showcase their artistic performances, culture, and traditions to Japanese audiences. In so doing, they witnessed and experienced lives outside their conflict-affected circumstances. Given their difficult situations and the level of resources available in these conflict-affected regions, it would have been highly improbable for them to exhibit their creative arts without support from the Japan Foundation and other NGOs. Also, these projects provide the Japanese audiences with great opportunities to increase their awareness of the circumstances in these conflictaffected regions, as well as learn about other cultures and traditions through the performances. To a greater extent, these domestic projects served as a set of venues for both foreign performers and the domestic audiences to foster intercultural communication and share a mutual understanding of their worlds.

Fourth, recreational activities related to sport are rare. There was only one project that directly encompasses sport activities. Project 8 called "Peace Kids Soccer" was organized by a Japanese NGO together with support from the Japan Foundation in 2004, 2005, and 2006 consecutively. Two characteristics were noteworthy. First, the event took place in a third-party country, Japan in this case. Children from both Israel and Palestine were invited to Japan for a tenday recreational sporting activity and spent their time playing soccer together. Second, while this was a recreational sporting activity, other creative and cultural activities such as creative dance, paper folding, also known as origami, net fishing, music, and cooking were also incorporated. By organizing recreational sporting events alongside other creative activities, the project encouraged them to communicate with each other through sport in order to foster mutual understanding despite their prolonged antagonistic backgrounds.

Finally, despite the fact that all projects encompass various means to improve psychosocial reconstruction in one way or another, no project aimed directly at treating PTSD. One possible reason for this absence is that, as has been noted earlier, children who are highly traumatized by their violent experiences often require ongoing psychiatric treatment. This involves highly specialized knowledge of mental health and psychology. In this light, it is conceivable that all of the Japan Foundation's projects deprioritized any activities related to the treatment of children's PTSD because of the nature of the treatment. In short, psychotherapy and active and long-term counselling were considered out of scope of the projects.

Overall, the analysis based on the theoretical framework of psychosocial reconstruction indicates that Japan does encompass psychosocial reconstruction of those who are living in conflict-affected regions as its part of peacebuilding. Creative and recreational activities in particular art are the central components 
of these reconstruction efforts. To a lesser extent, there are some cases that put a strong emphasis on community-building by strengthening social networks and by promoting local intercultural communication.

However, the fact that almost half of the projects took place in Japan leads us to make a critical observation. That is, it is uncertain whether, and to what extent, these projects have had a direct and positive impact on fulfilling the need of psychosocial well-being of those local children who are living in conflict-affected areas. Surely those participants who were invited to Japan had the chance to enlarge their networks in their creative fields and to have an interesting experience overseas. This is not to suggest that these projects are less effective in meeting the needs of those who do participate and that they need to be downscaled. Rather, it is to point out that it is not always apparent whether these invited participants have managed to redistribute their knowledge, skills, and experiences earned from the projects held in Japan to other local children who still need long-term support for their psychosocial fulfillment. A similar critical observation regarding recreational activities such as the soccer project can be made as well. That is, the effects of the project on other children in Israel and Palestine remains unknown while the children invited to Japan likely had invaluably positive experiences.

\section{Broader Implications of Psychosocial Reconstruction for Japan's Foreign Policy}

This article has discussed the change and continuity of Japan's foreign policy in particular reference to human security and peacebuilding in the recent context of Prime Minister Abe's security legislation reforms. While some may see this change as Japan becoming more assertive, I have argued that Japan maintains its non-coercive approach to its peacebuilding activities considering the continued relevance of human security to these activities. The analysis conducted in this article also reinforces this argument for three reasons in relation to psychosocial reconstruction as part of Japan's peacebuilding. First, psychosocial reconstruction is organized primarily by the Japan Foundation, a semi-government agency that does not get involved in defense policy, or NGOs that receive support from the agency. Second, because the implementers are civilians working on the basis of a non-military approach to peacebuilding, projects for psychosocial reconstruction are also highly civilian-oriented. Third, the purpose of psychosocial reconstruction is largely self-explanatory; a sense of psychosocial well-being is highly unlikely to be fulfilled through forceful means. No one can build and nurture a sense of well-being, community, and belonging for those who are traumatized by conflict with an iron fist.

Japan's involvement in psychosocial reconstruction has important policy 
implications. Psychological reconstruction of children in conflict-affected regions can be another area of expertise in which Japan can fulfill domestic, local, and international demands. As Kurusu rightly points out, in order to improve and better promote the concept of human security, a psychological aspect is one that Japan needs to take into account because it can "bring a new perspective to human security discourse and policies" (Kurusu 2016, 43). Also, as peace psychologists convincingly point out (Kalksma-Van Lith 2007; Wessells and Monteiro 2001), promoting of a sense of psychosocial well-being is a vital source of durable peace. Internationally, the fulfillment of such needs is highly compatible with UNSECO's constitution and the recent growing demand for building a culture of peace. Better incorporation of an intangible dimension into already existing areas of expertise (political, economic, material, and human contributions) gives Japan an opportunity to extend its own non-military peacebuilding in conflict-affected regions without prioritizing one demand over the other two. In short, it will be a win-win-win situation.

Furthermore, because peacebuilding activities are so diverse that often one cannot do every single task, some countries are more prepared to take a military role in peacebuilding than other countries are. Others focus more on preventive diplomacy, mediation, and reconciliation. Given Japan's limited resources together with its domestic normative constraints and international expectations, it is not impossible for Japan to create an international division of labor among other countries such as the U.S., Canada, and Germany by incorporating psychosocial reconstruction with already existing activities (namely taking political leadership in international forums, participating in non-combat peacekeeping operations, providing ODA to conflict parties as a vital incentive for bringing peace, and developing human resources for HPC in order to foster civilian peacebuilders). It can be Japan's comparative advantage in the international peacebuilder community. In turn, Japan may be able to carve out a niche in the field of international peacebuilding as a non-military peacebuilder, and it may be an important way to enhance its international status in the community.

\section{Conclusion}

This article has examined Japan's role in one specific area of peacebuilding, psychosocial reconstruction among children in conflict-affected regions. By employing the theoretical framework of peace psychologists, it has highlighted the increasing relevance of psychosocial reconstruction to the concept of human security and the praxis of Japan's peacebuilding. There is evidence that Japan has prioritized creative and recreational activities as well as community-building techniques as vital tools to promote a sense of psychosocial well-being among children, whereas it has put no emphasis on psychiatric treatment for PTSD. 
This article has argued that psychosocial reconstruction can be an additional strength of Japan's peacebuilding praxis if we accept peace psychologists' claim that the fulfillment of a sense of psychosocial well-being is a vital component of a comprehensive peacebuilding processes.

However, it is valuable to identify four shortcomings of this article and therefore some agendas for further research. First, this article has focused primarily on the role of a national-level agency, the Japan Foundation, in psychosocial reconstruction. However, it lacks insight into the roles of NGOs. While some projects were organized by the Japan Foundation on its own initiative, others were organized by the NGOs with the Japan Foundation serving as the main source of financial support. An in-depth analysis on how the NGOs initiated these projects and how the Japan Foundation collaborated with them will provide us with a better understanding of more precise purposes and means to Japan's psychosocial reconstruction activities in peacebuilding. In turn, it will highlight government-civil society cooperation in the field of peacebuilding.

Second, this article did not address the roles of other key national agencies in this field such as MOFA, JICA, and the Japanese Ministry of Defense/SDF. Further research on their roles can shed light on their priorities, purposes, and means to contribute to international peacebuilding. Understanding these aspects is particularly critical because it will be allow researchers to highlight ways and means to develop integrated approaches to complex processes of peacebuilding. As some scholars on Japan's peacebuilding have already pointed out, one serious shortcoming of Japan's peacebuilding is a lack of inter-agency coordination and a "whole-of-government" approach (Ashizawa 2014; Uesugi 2012b). This problem was also recognized in the 2014 recommendation report of the Advisory Panel on Peacebuilding to Prime Minister Abe (Advisory Panel on Peacebuilding 2014). A further analysis on this point may be able to show ways for Japan to overcome "a major institutional shortcoming in the area of peacebuilding assistance" (Ashizawa 2014, 11).

Third, this article cannot explain why Japan takes part in psychosocial reconstruction in peacebuilding beyond the reasons noted above such as a domestic conformity to the non-military approach to peacebuilding, expectations from peace psychologists who study conflict-affected communities, and international norms. Is it part of Japan's strategic policy to implement its cultural and public diplomacy given the fact that the Japan Foundation plays the central role? It is still unclear whether the involvement of the Japan Foundation in psychosocial reconstruction is Japan's overall strategy to exercise its soft power or it is motivated by altruism.

Finally, this article has primarily focused on psychosocial reconstruction among children, but what about adults? What are effective measures Japan can employ in order to promote better psychosocial reconstruction processes among adults? Further research needs to be undertaken in light of this. 
As noted earlier, ensuring a great degree of stability in material and security terms in conflict-affected regions is often considered the priority of peacebuilding. This paper does not challenge this observation. Peacemaking by military and diplomatic means is often the core process of peacebuilding. Provision of emergency humanitarian aid and long-term financial assistance are also key sources for bringing durable and resilient peace back to conflictaffected regions. Rather, this paper has argued that psychosocial reconstruction is also a vital component of peacebuilding that we often overlook. If peacebuilding continues to be the hallmark of Japan's foreign policy, then it is imperative for the country to develop a more coordinative policy in light of this psychosocial aspect.

\section{Acknowledgements}

I am grateful to the editorial board team, particularly Sung Chull Kim and Benjamin A. Engel, and two anonymous referees. Also my appreciation goes to Naimah Talib who gave me an opportunity to present an earlier version of this article at the 21st New Zealand Asian Studies Society International Conference in Christchurch, New Zealand in December 2015. I am also grateful to the members of the audience at the conference, Micheal Harland, James Headley, Akiko Nanami, Takao Sebata, and Lena Tan for their valuable comments and suggestions.

\section{References}

Advisory Panel on Peacebuilding. 2014. "Heiwakōchiku Bunya ni kansuru Yūshikisha Kondankai Teigen" [Reccommendation of the Advisory Panel on Peacebuilding]. http://www.mofa.go.jp/mofaj/files/000035636.pdf (accessed July 14, 2015).

Ashizawa, Kuniko. 2014. "Japan's Approach to Peacebuilding in Afghanistan: Money, Diplomacy and the Challenges of Effective Assistance." Journal of Peacebuilding \& Development 9 (3): 1-16.

Carvalho, Pedro Amakasu Raposo, and Potter, David M. 2016. "Peacebuilding and the 'Human Securitization' of Japan's Foreign Aid.' In The Securitization of Foreign Aid, edited by Stephen Brown and Jörn Grävingholt. Hampshire: Palgrave Macmillan.

Christie, Daniel J., Wagner, Richard V. and Winter, Deborah Du Nann. 2001. "Introduction to Peace Psychology." In Peace, Conflict, and Violence: Peace Psychology for the 21st Century, edited by Daniel J Christie, Richard V. Wagner and Deborah Du Nann Winter, 1-14. New Jersey: Prentice Hall.

CPCD (The Council on the Promotion of Cultural Diplomacy). 2005. "Establishing Japan as a "Peaceful Nation of Cultural Exchange." http://japan.kantei. go.jp/policy/bunka/050711bunka_e. html (accessed August 14, 2015).

Edström, Bert. 2011. Japan and Human Security: The Derailing of a Foreign Policy Vision 
Stockholm-Nacka: Institute for Security \& Development Policy.

Fukushima, Akiko. 2008. "Hōkatsuteki Heiwakōchiku Kō: Bunka no Shiza kara" [Comprehesive Peacebuilding: From the Cultural Perspective]. Kokusai Kōkyō Seisaku Kenkyū 13 (1): 89-99.

Gilson, Julie. 2007. "Building Peace or Following the Leaders?: Japan's Peace Consolidation Diplomacy." Pacific Affairs 80 (1): 27-47.

Honna, Jun. 2012. "Japan and the Responsibility to Protect: Coping with Human Security Diplomacy." Pacific Review 25 (1): 95-112.

Ishikawa, Sachiko. 2015. "The Role of a Development Agency in Peacebuilding: Trak Oneand-a-Half Mediation in Mindanao.” Asian Journal of Peacebuilding 2 (1): 79-95.

Ishizuka, Katsumi. 2005. "Japan’s Policy Towards U.N. Peacekeeping Operations." International Peacekeeping 12 (1): 67-86.

Ishizuka, Katsumi. 2006. “Japan’s New Role in Peace-Building Missions." East Asia 23 (3): 3-21.

Iwami, Tadashi. 2016. "Understanding Japan's Peacebuilding in Concept and Practice." East Asia 33 (2): 111-132.

Japan Foundation. 2008a. "Aceh Kodomo Kaigi” [Children's Conference in Aceh]. https:// www.jpf.go.jp/j/project/intel/archive/information/0808/08-01.html (accessed August $15,2016)$.

Japan Foundation. 2008b. The Roles of Cultural Initiatives in Peacebuilding. Tokyo: The Japan Foundation.

Japan Foundation. 2010. "Dai 2 Kai Ache no Kodomo tachi to Tsukuru Engeki Wakushoppu” [2nd Theater Workshop for Children in Aceh]. https://www.jpf.go.jp/j/ project/intel/archive/information/1012/12-01.html (accessed August 15, 2016).

Japan Foundation. 2013. "Suriranka niokeru Bunka wo tsujita Heiwakochiku Jigyo: Seika Hokoku Shimpojium" [Symposium on Reconciliation through Culture: Randooga in Sri Lanka, Accomplishments and Perspectives]. https://www.jpf.go.jp/j/project/intel/ archive/information/1312/12-03.html (accessed August 15, 2016).

Japan Times. 2016. "SDF Likely to be Handed New Security Duties in South Sudan as Early as November." August 7. http://www.japantimes.co.jp/news/2016/08/07/national/ politics-diplomacy/sdf-likely-handed-new-security-duties-south-sudan-earlynovember/ (accessed August 19, 2016).

Kalksma-Van Lith, Brechtje. 2007. "Psychosocial Interventions for Children in WarAffected Areas: The State of the Art." Intervention 5 (1): 3-17.

Kennedy, John F. 1963. "President Kennedy’s UNICEF Appeal - John F. Kennedy Presidential Library \& Museum.” https://www.jfklibrary.org/Research/Research-Aids/ Ready-Reference/JFK-Fast-Facts/Appeal-UNICEF.aspx (accessed August 18, 2016).

Kurusu, Kaoru. 2011. "Japan as an Active Agent for Global Norms: The Political Dynamism Behind the Acceptance and Promotion of 'Human Security." Asia-Pacific Review 18 (2): 115-137.

Kurusu, Kaoru. 2016. "Does the Concept of Human Security Generate Additional Value? An Analysis of Japanese Stakeholders Perceptions." JICA-RI Working Paper 122.

Lam, Peng Er. 2007. “Japan's Quest for 'Soft Power': Attraction and Limitation." East Asia 24 (4): 350-363.

Lam, Peng Er. 2009. Japan's Peace-Building Diplomacy in Asia: Seeking a More Active Political Role. Hoboken: Taylor \& Francis. 
Lam, Peng Er. 2013. “Japan’s Human Security and Peace-Building: Between Aspirations and Limitations." In Japan's Strategic Challenges in a Changing Regional Environment, edited by Purnendra Jain and Peng Er Lam, 177-199. Singapore: World Scientific Publishing.

Levermore, Roger, and Beacom, Aaron. 2009. Sport and International Development. Hampshire: Palgrave Macmillan.

Liff, Adam P. 2015. “Japan's Defense Policy: Abe the Evolutionary." The Washington Quarterly 38 (2): 79-99.

Mayor, Federico. 1995. "How Psychology Can Contribute to a Culture of Peace." Peace and Conflict: Journal of Peace Psychology 1(1): 3-9.

Ogura, Kazuo. 2010. Nihon no Bunka Gaikō [Japan's Cultural Peacebuilding]. Tokyo: Japan Foundation.

Ogura, Kazuo. 2012. Interview with author in Tokyo, July 25, 2012.

Osei-Hwedie, Bertha. 2011. “Japan in Africa: Building Sustainable Peace." South African Journal of International Affairs 18 (1): 87-105.

Peachey, Jon Welty, et al. 2015. "The Influence of a Sport-for-Peace Event on Prejudice and Change Agent Self-Efficacy." Journal of Sport Management 29 (3): 229-244.

Schnitzer, Marcy, et al. 2013. "Theorizing the Role of Sport for Development and Peacebuilding." Sport in Society 16 (5): 595-610.

Shank, Michael, and Schirch, Lisa. 2008. "Strategic Arts-Based Peacebuilding." Peace \& Change 33(2): 217-242.

Uesugi, Yūji. 2012a. "Building a Foundation for Regional Security Architecture in the AsiaPacific: Human Resource Development for Peacebuilding." In Bilateral Perspectives on Regional Security: Australia, Japan and the Asia-Pacific Region, edited by William T. Tow \& Rikki Kersten, 200-213. Hampshire: Palgrave Macmillan.

Uesugi, Yūji. 2012b. "PKO kara ODA e: Heiwakōchiku no Renzokusei wo Kangaeru" [From PKO to ODA: Considering the Continuity of Peacebuilding]. Gaikō 12: 134-139.

UNESCO (United Nations Educational Scientific and Cultural Organization). 1945. "UNESCO Constitution." http://portal.unesco.org/en/ev.php-URL_ID=15244\&URL_ DO=DO_TOPIC\&URL_SECTION=201.html (accessed August 12, 2016).

United Nations General Assembly. 1992. "An Agenda for Peace: Preventive Diplomacy, Peacemaking, Peace-keeping: Report of the Secretary-General Pursuant to the Statement Adopted by the Summit Meeting of the Security Council." http://www. un.org/ga/search/view_doc.asp?symbol=A/47/277 (accessed July 15, 2015).

United Nations General Assembly. 1997. "Culture of Peace (A/RES/52/13)." http://www. un.org/ga/documents/gares52/res5213.htm (accessed August 13, 2016).

Wessells, Michael, and Monteiro, Carlinda. 2001. "Psychosocial Intervention and PostWar Reconstruction in Angola: Interweaving Western and Traditional Approaches.” In Peace, Conflict, and Violence: Peace Psychology for the 21st Century, ed. Daniel J Christie, Richard V. Wagner and Deborah Du Nann Winter, 262-276. New Jersey: Prentice Hall.

Zelizer, Craig. 2003. "The Role of Artistic Processes in Peace-Building in BosniaHerzegovina." Peace and Conflict Studies 10 (2): 62-75. 
Tadashi Iwami is a Lecturer at the Faculty of International Studies, the Institute of the Pacific United (IPU) in New Zealand. He obtained his M.A. in Political Science from the University of Canterbury, and has recently received his Ph.D. in Politics from the Department of Politics, University of Otago, New Zealand. His research interests include Japan's peacebuilding, international relations, and identity studies. His recent article on Japan's peacebuilding in concept and practice appears in East Asia: An International Quarterly. Contact: iwami.tadashi@gmail.com

Submitted: May 13, 2016; Revised: September 2, 2016; Accepted: September 8, 2016 
